\title{
MODIFIKASI RUANG STERILISASI MEDIA TANAM JAMUR UNTUK MENGURANGI KEGAGALAN PRODUK JAMUR TIRAM
}

\author{
Ign. Riyadi Mardiyanto, Maridjo, Ratriana Astuti \\ Jurusan Teknik Konversi Energi - Politeknik Negeri Bandung \\ Jl. Gegerkalong Hilir, Ds Ciwaruga - Bandung 40551 \\ Email: Ig_R_M@yahoo.com
}

\begin{abstract}
Sterilization room of mushrooms baglog is function to kill bacteria, or any type of life in the mushroom baglog so when the planting of oyster mushrooms, not wild mushrooms are disturbing. Most of the oyster mushroom farmers in Indonesia are still traditional mushroom farmers. They sterilize the baglog based only on experience - previous experience. Mushroom farmers during the sterilization process using sterilization room shaped pan with a total time of sterilization during the nine hours, to reach $90.7^{\circ} \mathrm{C}$ temperature baglog takes eight hours. Thus are requiring a lot of fuel which ultimately adds to the cost of production. By doing this modification, aiming to reduce the failure rate and save fuel in the process of sterilization. From the results of the modification and testing can reduce the failure rate on mushroom growing media up to $65.48 \%$ and can save fuel up to $66.67 \%$.
\end{abstract}

\section{PENDAHULUAN}

Kebanyakan petani jamur tiram di Indonesia masih merupakan petani jamur tradisional. Mereka mensterilkan media tanam hanya berdasarkan pengalaman sebelumnya. Peralatan yang digunakan untuk proses sterilisasi media tanam terbuat dari drum bekas.

Jamur tiram adalah jenis jamur kayu yang memiliki kandungan nutrisi lebih tinggi dibandingkan dengan jenis jamur kayu lainnya. Jamur tiram mengandung protein, lemak, fospor, besi, thiamin dan riboflavin lebih tinggi dibandingkan dengan jenis jamur lain. Jamur tiram mengandung 18 macam asam amino yang dibutuhkan oleh tubuh manusia dan tidak mengandung kolesterol.

Jamur tiram bisa hidup pada daerah yang bersuhu antara $10^{\circ} \mathrm{C} \mathrm{s} / \mathrm{d} 32^{\circ} \mathrm{C}$. Artinya bila suhu $<10^{\circ} \mathrm{C}$ jamur tiram tumbuh kurang baik demikian pula apabila $>32^{\circ} \mathrm{C}$. Pertumbuhan optimum jamur tiram adalah pada suhu $25^{\circ} \mathrm{C}$ $26^{\circ} \mathrm{C}$. Secara alamiah daerah di Indonesia yang mempunyai suhu $25^{\circ} \mathrm{C}-26^{\circ} \mathrm{C}$ terdapat di dataran tinggi kira-kira pada ketinggian $500-1000 \mathrm{~m}$ diatas permukaan laut.

Media tanam yang digunakan dalam penanaman jamur tiram putih adalah serbuk kayu, bekatul, kapur dan air.
Keyword : sterilization, baglog, mushrooms

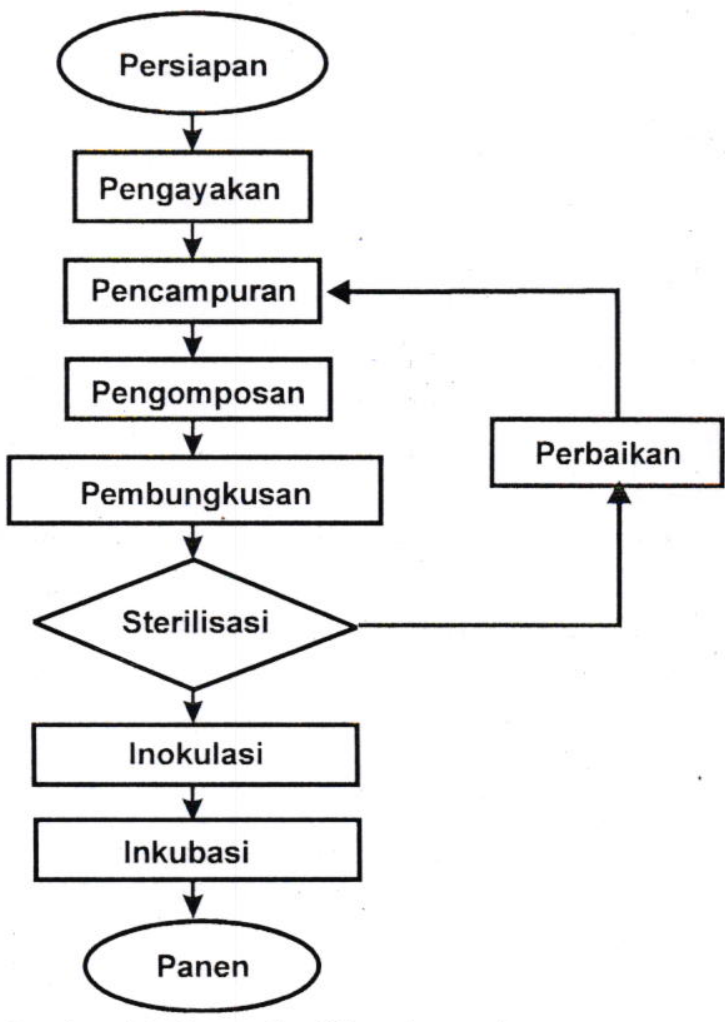

Gambar 1. Tahapan budidaya jamur tiram

Proses sterilisasi sangat penting, karena bertujuan menekan pertumbuhan mikroba seperti bakteri, kapang dan khamir atau ragi yang dapat menghambat pertumbuhan jamur tiram. 
Kegagalan panen banyak disebabkan karena proses sterilisasi baglog kurang sempurna. Jamur-jamur liar yang masih ada dalam baglog akan tumbuh subur dan menghambat pertumbuhan jamur utama jika proses sterilisasi tidak sempurna.

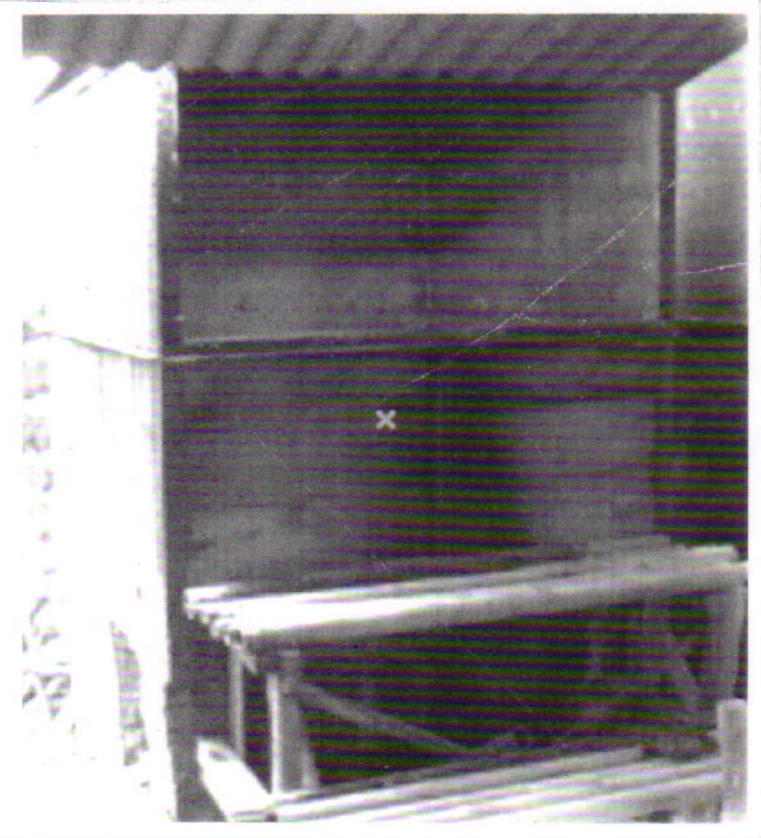

Gambar 2 Ruang Sterilisasi dan ketel uap tradisional

\section{KEBUTUHAN ENERGI STERILISASI}

Besarnya energi yang dibutuhkan untuk media tanam jamur yang diinginkan dapat dihitung dengan rumus sebagai berikut:

Dimana :

$$
\mathrm{Q}=\mathrm{m} \cdot \mathrm{C}_{\mathrm{p}} \cdot\left(\mathrm{T}_{1}-\mathrm{T}_{2}\right)
$$

$$
\begin{aligned}
\mathrm{Q} & =\text { Energi } \\
\mathrm{C}_{\mathrm{p}} & =\text { Kalor spesifik serbuk gergaji }\left(\mathrm{kJ} / \mathrm{kg}{ }^{\circ} \mathrm{C}\right) \\
\mathrm{T}_{1} & =\text { Temperatur uap }\left({ }^{\circ} \mathrm{C}\right) \\
\mathrm{T}_{2} & =\text { Temperatur media tanam }\left({ }^{\circ} \mathrm{C}\right) \\
\mathrm{m} \cdot & =\text { Massa media tanam }(\mathrm{kg})
\end{aligned}
$$

Kualitas uap didefinisikan sebagai rasio uap jenuh kering per satu kilogram uap jenuh. Kualitas uap merupakan indikator bagi tingkat kekeringan suatu uap jenuh. Besarnya kualitas uap ini umumnya diekspresikan dalam bentuk desimal.

$$
x-\frac{h_{2}-h_{f l}}{h_{f g l}}
$$

$$
\begin{array}{ll}
X & =\text { kualitas uap } \\
h_{2} & =\text { entalpi uap yang diinginkan } \\
h_{f l} & =\text { entalpi cairan jenuh uap masuk } \\
h_{f g l} & =\text { entalpi penguapan uap masuk }
\end{array}
$$

\section{RENCANA MODIFIKASI RUANG STERILISASI}

Modifikasi ruang sterilisasi dibuat dengan cara sederhana dan mudah dalam pemeliharaan. Aliran uap dibuat dalam 2 tahap, yaitu masuk kè dalam pipa uap dan mengalir ke atas melalui lubang uap. Hal ini dimaksudkan agar uap dapat mengalir ke ruang sterilisasi dengan cepat secara merata.
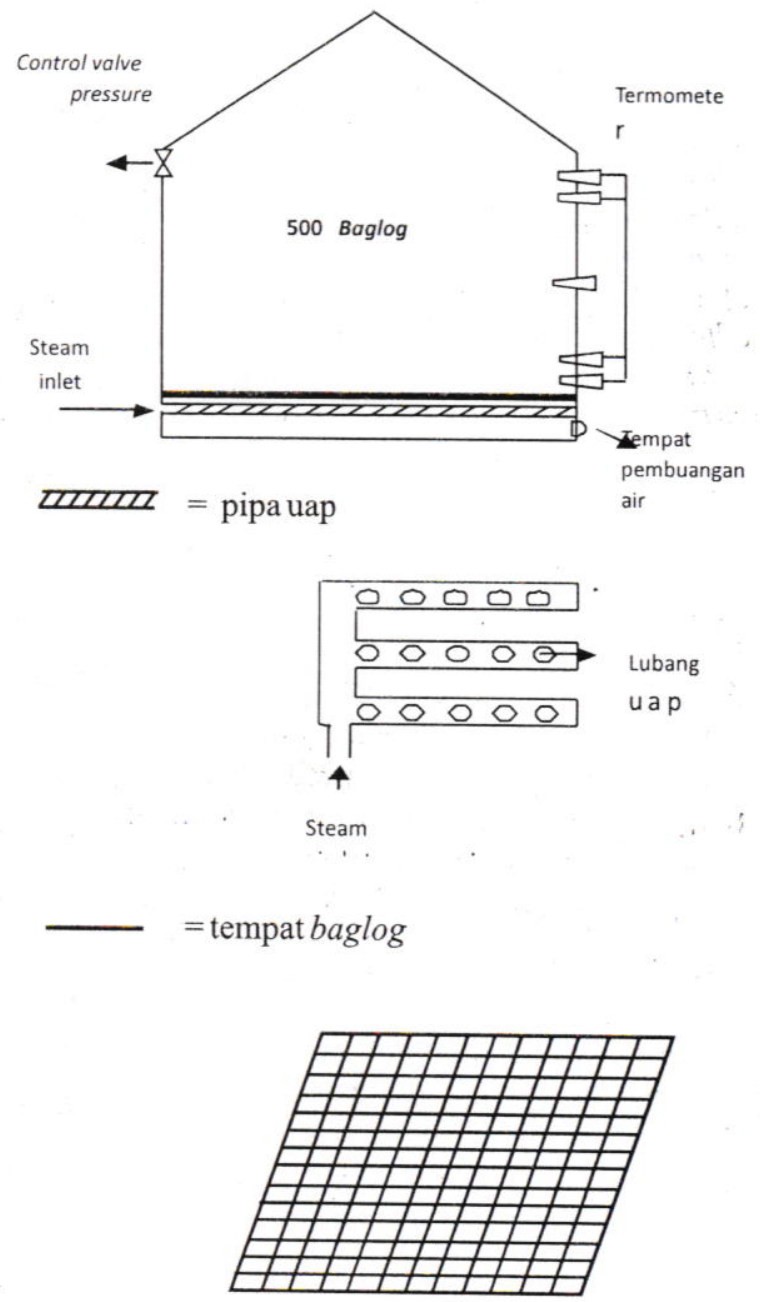

Gambar 3 Skematik hasil modifikasi Ruang Sterilisasi

Bahan yang digunakan untuk pembuatan atau perakitan reaktor tungku adalah:

$>$ Dinding atap menggunakan plat aluminium $0,8 \mathrm{~mm}$

$>$ Pipa penyalur uap menggunakan pipa black stell welded $3 / 4$ inchi 


\section{Ruang Sterilisasi}

Prinsip Kerja ruang sterilisasi adalah uap akan mengalir dari boiler ke ruang sterilisasi melalui pipa penghubung.

Baglog yang akan disterilisasi berjumlah 500 dengan posisi miring atau tidur yang telah diatur di atas tempat baglog atau kassa. Uap yang bertemperatur $95^{\circ} \mathrm{C}$ masuk ke ruang sterilisasi akan mengalir ke atas melalui lubang-lubang pipa. Uap dibiarkan mengalir terus selama 2 jam dan dipertahankan pada suhu $95^{\circ} \mathrm{C}$ selama 25 menit.

Untuk mengetahui dan menjaga temperatur uap, dipasang termometer yang ditempatkan di bagian atas, tengah dan bawah ruang sterilisasi yang berhubungan langsung dengan ruang uap. yaitu:

Langkah-langkah pengujian ruang uap

1. Menyusun media tanam dengan posisi miring atau tidur;

2. Tutup rapat pintu dari ruang sterilisasi sehingga tidak ada uap yang keluar;

3. Mencatat temperatur pada titik-titik pengukuran (Gambar 4);

4. Pengujian sterilisasi ini dilakukan sampai baglog mencapai temperatur $94^{\circ} \mathrm{C}$ dan dipertahankan selama 25 menit;

5. Setelah pengujian selesai dilakukan analisis data.
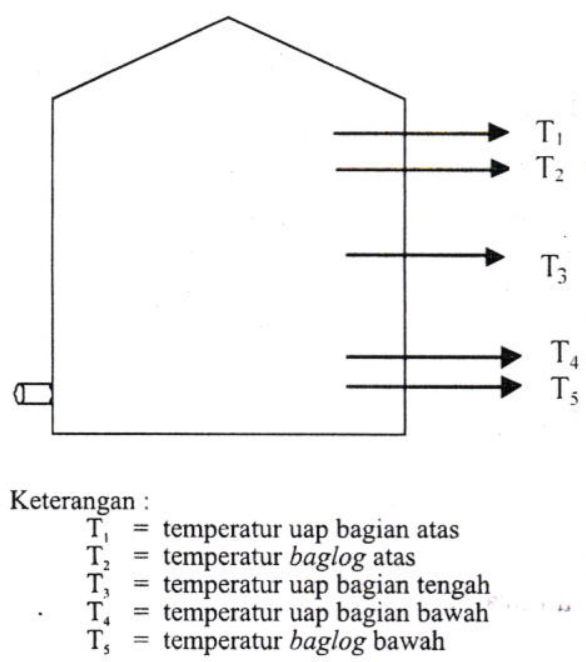

Gambar 4: Pemantauan Panas pada Ruang Sterilisasi
Tabel . Target total waktu yang dibutuhkan untuk proses sterilisasi

\begin{tabular}{|c|c|c|c|}
\hline No & $\begin{array}{c}\text { Temperatur } \\
\left({ }^{\circ} \mathrm{C}\right)\end{array}$ & $\begin{array}{c}\mathrm{m}_{\mathrm{u}} \\
(\mathrm{kg})\end{array}$ & $\begin{array}{c}?_{\mathrm{u}} \\
(\mathrm{kg} / \mathrm{jam})\end{array}$ \\
\hline 1 & 104.8 & 72 & 36 \\
\hline 2 & 95 & 62,75 & 31,375 \\
\hline 3 & 90 & 57,5 & 28,75 \\
\hline 4 & 85 & 53 & 26,5 \\
\hline
\end{tabular}

\begin{tabular}{|c|c|c|c|}
\hline $\begin{array}{c}\text { Q } \\
\text { (kJ/jam) }\end{array}$ & $\begin{array}{c}\text { Waktu } \\
\text { (jam) }\end{array}$ & $\begin{array}{c}\text { Waktu mati } \\
\text { bakteri (menit) }\end{array}$ & $\begin{array}{c}\text { Total waktu } \\
\text { (jam) }\end{array}$ \\
\hline 91290,97 & 2 & 20 & 2.20 \\
\hline 79528,44 & 2 & 25 & 2.25 \\
\hline 73403,03 & 2 & 35 & 2.35 \\
\hline 67449,84 & 2 & 80 & 3.20 \\
\hline
\end{tabular}

Catatan : target menghasilkan $\mathrm{m}_{\mathrm{u}}$ selama 2 jam dan total waktu belum ditambahkan dengan waktu boiler menghasilkan uap hingga temperatur yang ditentukan.

\section{HASIL MODIFIKASI}

Pengambilan data existing dilakukan pada tanggal 15 dan 22 Mei 2010. Dan pengambilan data setelah dilakukan modifikasi pada tanggal 17 dan 18 Juli 2010.

Tabel 2 Data Existing Proses Sterilisasi (15 Mei 2010)

\begin{tabular}{|l|l|l|l|l|l|l|l|}
\hline No. & Waktu & T1 $\left({ }^{\circ} \mathrm{C}\right.$ & T2 $\left({ }^{\circ} \mathrm{C}\right)$ & $\mathrm{T} 3\left({ }^{\circ} \mathrm{C}\right)$ & T4 $\left(^{\circ}\right)$ & T5 $\left({ }^{\circ} \mathrm{C}\right.$ & T6 $\left({ }^{\circ} \mathrm{C}\right)$ \\
\hline 1. & 10.00 & 24.9 & 26.9 & 25.5 & 30.2 & 27.1 & 30.5 \\
\hline 2. & 10.30 & 27.7 & 28.1 & 26.8 & 46.8 & 35.3 & 50.4 \\
\hline 3. & 11.00 & 30.5 & 28.4 & 33.2 & 61.6 & 50.9 & 68.1 \\
\hline 4. & 11.30 & 41.2 & 29.8 & 46.3 & 74.8 & 69.4 & 79.2 \\
\hline 5. & 12.00 & 51.1 & 32.4 & 53.8 & 73.4 & 69.7 & 84.1 \\
\hline 6. & 12.30 & 58.4 & 38.2 & 55.9 & 74.1 & 69.8 & 84.3 \\
\hline 7. & 13.00 & 63.7 & 44.6 & 55.6 & 76.1 & 72 & 83.9 \\
\hline 8. & 13.30 & 67.7 & 49.5 & 56.4 & 75.3 & 71.3 & 83.1 \\
\hline 9. & 14.00 & 71.3 & 55.2 & 58.9 & 78.2 & 74.4 & 87.2 \\
\hline 10. & 14.30 & 78.6 & 61.2 & 68.3 & 81.7 & 78.6 & 89.9 \\
\hline 11. & 15.00 & 78.4 & 68.3 & 61.6 & 80.7 & 79.1 & 89.1 \\
\hline 12. & 15.30 & 83.4 & 73.7 & 77.5 & 87.2 & 86.1 & 94.2 \\
\hline 13. & 16.00 & 83.1 & 78.6 & 80.6 & 86.6 & 85.2 & 94.8 \\
\hline 14. & 16.30 & 82.5 & 79.7 & 73.5 & 84.5 & 84.3 & 92.2 \\
\hline 15. & 17.00 & 81.7 & 81.5 & 73.9 & 82.1 & 82 & 91.1 \\
\hline 16. & 17.30 & 92.4 & 85.7 & 92.8 & 92.8 & 92 & 95.4 \\
\hline 17. & 18.00 & 92.5 & 91.1 & 94.5 & 94.1 & 92.9 & 96.7 \\
\hline 18. & 18.30 & 91.2 & 92.3 & 92.3 & 90.9 & 93.1 & 95.6 \\
\hline 19. & 19.00 & 89.5 & 93.4 & 91.5 & 91.9 & 93.5 & 96.4 \\
\hline
\end{tabular}

Keterangan : $\mathrm{T} 2=$ Temperatur baglog atas 
$\mathrm{T} 3=$ Temperatur uap pada bagian tengah

$\mathrm{T} 4=$ Temperatur uap pada bagian bawah

T5 = Temperatur baglog bawah

$\mathrm{T} 6=$ Temperatur air

Jumlah baglog $=500$ buah

Jumlah baglog yang gagal $=168$ buah

Dari data hasil pengujian (Tabel 2), dapat dianalisa bahwa $\mathrm{T}_{6}$ (temperatur air) mencapai $90,2^{\circ} \mathrm{C}$ pada pukul 15.00 WIB, yaitu setelah 5 jam. $\mathrm{T}_{4}$ (temperatur uap pada bagian bawah) dan $\mathrm{T}_{1}$ (temperatur uap pada bagian atas) mencapai $91,7^{\circ} \mathrm{C}$ dan $93,2^{\circ} \mathrm{C}$ yaitu setelah 7,5 jam. Sedangkan $\mathrm{T}_{5}$ (Temperatur baglog bawah), $\mathrm{T}_{2}$ (baglog atas), $\mathrm{T}_{3}$ (Temperatur uap pada bagian tengah) diatas $90^{\circ} \mathrm{C}$ pada pukul 18.00 yaitu setelah 8 jam. Dengan nilai $\mathrm{T}_{5}=90,7^{\circ} \mathrm{C}, \mathrm{T}_{2}=$ $92,3^{\circ} \mathrm{C}$, dan $\mathrm{T}_{3}=93,2^{\circ} \mathrm{C}$. Jumlah baglog yang gagal sebanyak 168 buah, jadi persentase kegagalan baglog adalah 33,6\%.

Tabel 3 Data Proses Sterilisasi (17 Juli 2010)

\begin{tabular}{|ccc|c|c|c|c|c|}
\hline No & $\begin{array}{c}\text { Waktu } \\
(\mathrm{WIB})\end{array}$ & $\begin{array}{c}\mathrm{T} 1 \\
\left({ }^{\circ} \mathrm{C}\right)\end{array}$ & $\begin{array}{c}\mathrm{T} 2 \\
\left({ }^{\circ} \mathrm{C}\right)\end{array}$ & $\begin{array}{c}\mathrm{T} 3 \\
\left({ }^{\circ} \mathrm{C}\right)\end{array}$ & $\begin{array}{c}\mathrm{T} 4 \\
\left({ }^{\circ} \mathrm{C}\right)\end{array}$ & $\begin{array}{c}\mathrm{T} 5 \\
\left({ }^{\circ} \mathrm{C}\right)\end{array}$ & $\begin{array}{c}\mathrm{T} 6 \\
\left({ }^{\circ} \mathrm{C}\right)\end{array}$ \\
\hline 1 & 09,00 & 28.9 & 28.1 & 28.8 & 26.6 & 27.1 & 25.9 \\
\hline 2 & 09,30 & 46.6 & 65.3 & 61 & 82.8 & 72 & 85.2 \\
\hline 3 & 10,00 & 75.4 & 86.8 & 77.8 & 87.7 & 87 & 92.1 \\
4 & 10,30 & 77.7 & 87.7 & 78.2 & 89.5 & 87.6 & 94.1 \\
\hline 5 & 11,00 & 80.5 & 89.6 & 81.2 & 91.9 & 90.5 & 96.2 \\
\hline 6 & 11,30 & 85.9 & 94.2 & 86.5 & 94.3 & 94 & 96.3 \\
\hline 7 & 12,00 & $88: 8$ & 94.8 & 88.3 & 95.2 & 95.1 & 96.6 \\
\hline 8 & 12,30 & 89.5 & 95 & 89.2 & 95.4 & 95.3 & 97 \\
\hline 9 & 13,00 & 91.8 & 95.2 & 91.5 & 95.8 & 95.7 & 96.5 \\
\hline
\end{tabular}

Keterangan

$\mathrm{T} 1=$ Temperatur uap pada bagian atas

$\mathrm{T} 2=$ Temperatur baglog atas

$\mathrm{T} 3=$ Temperatur uap pada bagian tengah

$\mathrm{T} 4=$ Temperatur uap pada bagian bawah

T5 $=$ Temperatur baglog bawah

T6 = Temperatur air

Jumlah baglog $=500$ buah

Jumlah baglog yang gagal $=58$ buah

Dari data hasil pengujian (Tabel 3), dapat dianalisis bahwa $\mathrm{T}_{6}$ (temperatur air) mencapai $92,1^{\circ} \mathrm{C}$ pada pukul $10.00 \mathrm{WIB}$, dengan waktu 1 jam. $\mathrm{T}_{2}$ (baglog atas) mencapai $95^{\circ} \mathrm{C}$ pada pukul 12.30 WIB selama 3,5 jam dan $\mathrm{T}_{5}$ (Temperatur baglog bawah) mencapai $95,2^{\circ} \mathrm{C}$ pada pukul 12.00 WIB selama 3 jam. $\mathrm{T}_{5}$ (Temperatur baglog bawah) lebih cepat mencapai nilai $95,2^{\circ} \mathrm{C}$ dikarenakan posisi baglog yang berada di bawah sehingga lebih cepat terkena uap yang disuplai dari boiler. Jumlah baglog yang gagal sebanyak 58 buah, jadi persentase kegagalan baglog adalah $11,6 \%$.

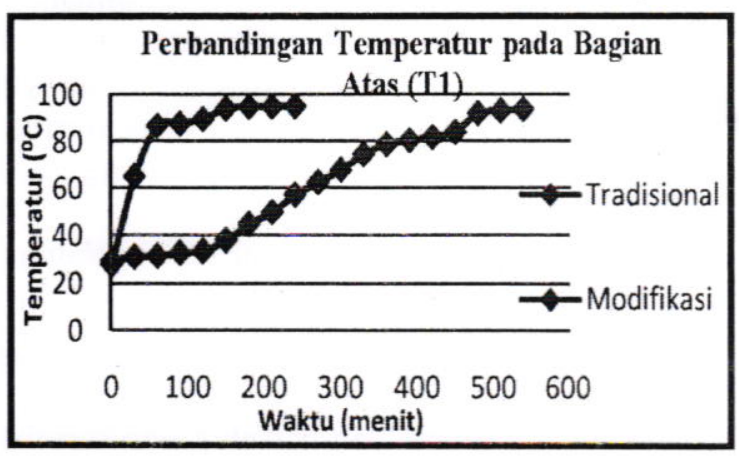

Gambar 3 Perbandingan temperatur uap bagian atas antara tradisional dengan yang sudah dimodifikasi

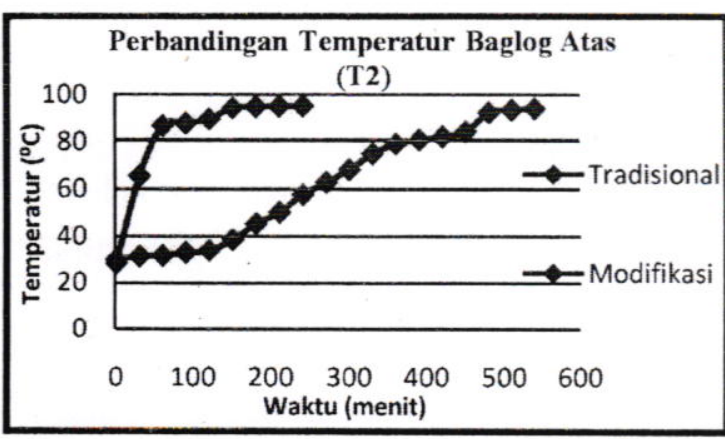

Gambar 4 Perbandingan temperatur baglog atas antara tradisional dengan yang sudah dimodifikasi

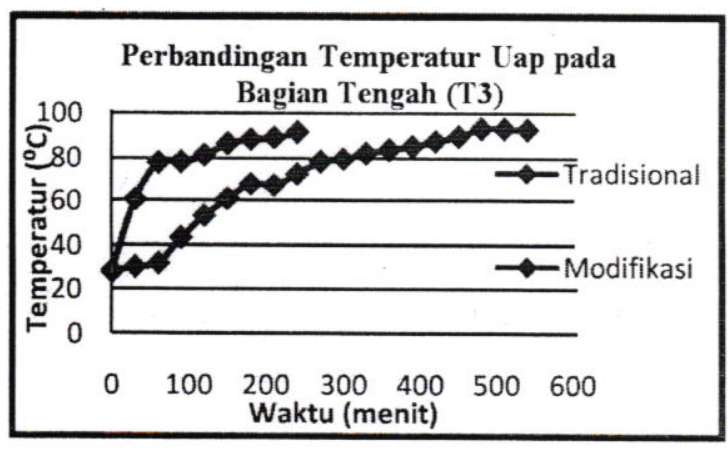

Gambar 5 Perbandingan temperatur uap bagian tengah antara tradisional dengan yang sudah dimodifikasi 


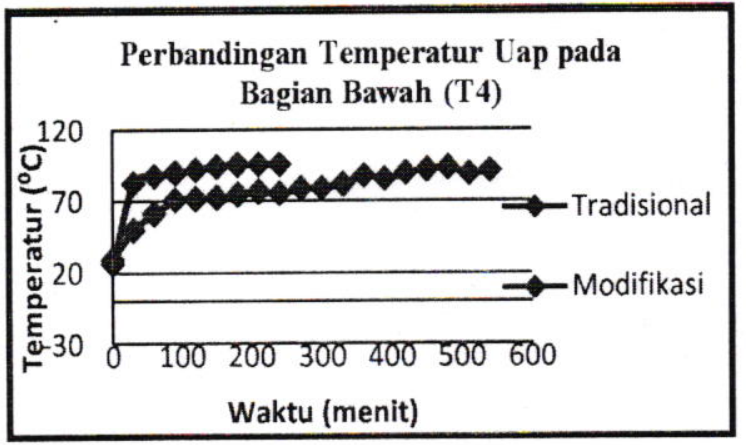

Gambar 6 Perbandingan temperatur uap bagian bawah antara tradisional dengan yang sudah dimodifikasi

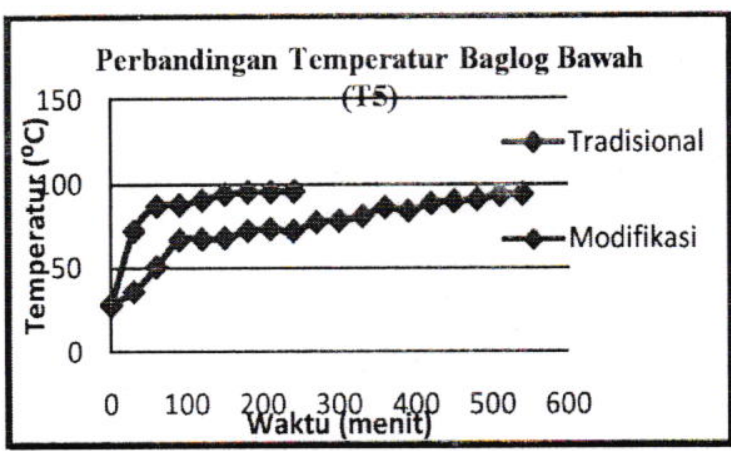

Gambar 7 Perbandingan temperatur baglog bawah antara tradisional dengan yang sudah dimodifikasi

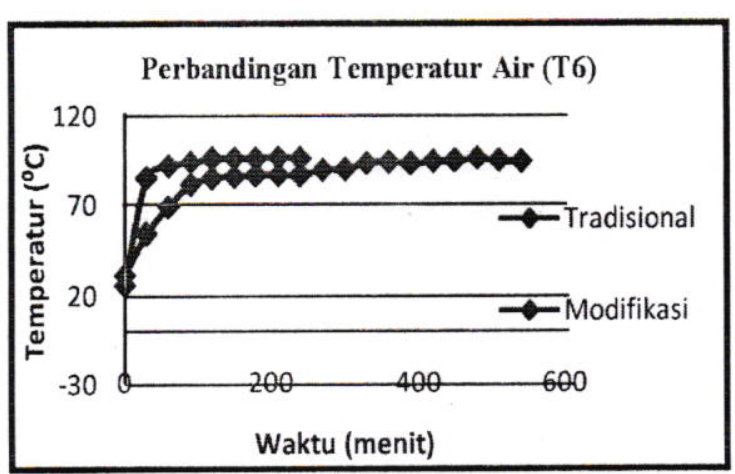

Gambar 8 Perbandingan temperatur air antara tradisional dengan yang sudah dimodifikasi

Dari grafik-grafik diatas dapat dianalisa bahwa pada proses sterilisasi menggunakan cara konvensional mencapai temperatur baglog $90.7^{\circ} \mathrm{C}$ dibutuhkan waktu selama 8 jam. Sedangkan pada proses sterilisasi menggunakan alat yang sudah dimodifikasi baglog mencapai temperatur $90,5^{\circ} \mathrm{C}$ dalam waktu 2 jam. Pada cara konvensional lama waktu proses sterilisasi selama 9 jam, sedangkan pada pengujian yang sudah dimodifikasi proses sterilisasi selama 4 jam.

\section{KESIMPULAN}

Dari hasil modifikasi dan analisa dapat disimpulkan bahwa, alat yang dimodifikasi kinerjanya lebih efektif dibandingkan dengan alat yang digunakan oleh petani (dandang tradisional), karena:

> Untuk mencapai temperatur $90^{\circ} \mathrm{C}$ lebih cepat 5,5 jam.

> Menghemat konsumsi bahan bakar hingga $66,67 \%$

$>$ Mengurangi tingkat kegagalan pada media tanam jamur hingga $65,48 \%$

\section{DAFTAR PUSTAKA}

\section{Pedoman Tugas Akhir - Jurusan Teknik}

\section{Konversi Energi :Politeknik Negeri Bandung}

2. Pasaribu, T. 2002. Aneka Jamur Unggulan yang Menembus Pasar. Jakarta: PT. Gramedia

3. Sri Yuniarti. 2007. Jamur Tiram Putih . $\mathrm{http} / / \mathrm{mikroba}$.wordpress.com/category/jam ur. Diakses Senin, 10 November 2008.

4. Moran, Michael J., Howard N. Shapiro. Fundamentals Of Engineering Thermodynamics. 5 th ed. West Sussex, England: John Willey \& Sons, Inc, 2006.

5. William Bowen Sarlos, dkk. 1956.Microbiology. Departrmen of Bacteriologi, University of Wisconsin. New York 